\title{
THREE DIMENSIONAL MODELING VIA PHOTOGRAPHS FOR DOCUMENTATION OF A VILLAGE BATH
}

\author{
H. B. Balta ${ }^{\mathrm{a}}$, M. Hamamcioglu-Turan ${ }^{\mathrm{a}}$, O. Ocali ${ }^{\mathrm{b}}$
}

\begin{abstract}
a Izmir Institute of Technology, Department of Architectural Restoration, IYTE, 35430, Urla, Izmir, Turkey (hamitbalta, mineturan)@iyte.edu.tr

b Ocali Software Inc., District of Technology Development, A1/Z-12, IYTE, 35430, Urla, Izmir, Turkey
\end{abstract}

KEY WORDS: Three dimensional modeling, photogrammetry, architectural conservation, Ottoman bath

\begin{abstract}
:
The aim of this study is supporting the conceptual discussions of architectural restoration with three dimensional modeling of monuments based on photogrammetric survey. In this study, a $16^{\text {th }}$ century village bath in Ulamıs, Seferihisar, and Izmir is modeled for documentation. Ulamıș is one of the historical villages within which Turkish population first settled in the region of Seferihisar Urla. The methodology was tested on an antique monument; a bath with a cubical form. Within the limits of this study, only the exterior of the bath was modeled. The presentation scale for the bath was determined as $1 / 50$, considering the necessities of designing structural interventions and architectural ones within the scope of a restoration project. The three dimensional model produced is a realistic document presenting the present situation of the ruin. Traditional plan, elevation and perspective drawings may be produced from the model, in addition to the realistic textured renderings and wireframe representations. The model developed in this study provides opportunity for presenting photorealistic details of historical morphologies in scale. Compared to conventional drawings, the renders based on the $3 \mathrm{~d}$ models provide an opportunity for conceiving architectural details such as color, material and texture. From these documents, relatively more detailed restitution hypothesis can be developed and intervention decisions can be taken. Finally, the principles derived from the case study can be used for $3 \mathrm{~d}$ documentation of historical structures with irregular surfaces.
\end{abstract}

\section{INTRODUCTION}

The betterment of the 3D modeling techniques for architectural heritage documentation is an on-going research problem. This study aims to search the potential of a newly developed software Tgi3D SU Photoscan v.1.27.9 for the conservation aimed 3D measured survey of historic monuments. This is manual photogrammetric evaluation software, which has been already tested on new buildings with prismatic forms presenting limited deformation and on small objects possessing organic forms such as sculpture pieces (http://www.tgi3d.com/index.php?Page=Gallery). It is expected that the experimental results of this study will provide contribution to the development of the software so that it can be efficiently used for historical building documentation. In order to test the software, a historical bath is selected as the case study. Three dimensional modeling of the exterior and interior features of the bath based on photogrammetric evaluation is experimented. Five experiments for the exterior surfaces and three for the interior surfaces were realized with targets. One experiment for the exterior surfaces was realized without targets.

The presentation scale and form is defined as $1 / 50$ colored renderings. The tools used during the field survey are a digital camera (Canon EOS 450D, 12.2 megapixels), a ladder for constituting variation in shooting angles, paper targets and putty. The tools used in the evaluation are Tgi3D Photoscan SU $1.27 \mathrm{v}$, Trimble Sketch-up 8 with Tgi3d plug-in and Computer (Intel i5, 1, 8 GHz, 4 GB DDR3 RAM, 1GB AMD Radeon HD 6470M Graphic Card).

Ulamış Hamam, which is in a village of Seferihisar district of the metropolitan city of Izmir, Turkey, is selected as the case study. Urla-Seferihisar region has been settled since the prehistoric era (Akurgal, 1993; Erkanal) as a result of its unique geographic characteristics. It is junction between the mainland Anatolia and the peninsula of Çeşme-Karaburun. The region has been settled by Turks starting with 1320s (Baykara). While Seferihisar and Urla were settlement centers, there were a number of villages in their rural site (Figure 1). Mosques, baths, children schools and fountains providing information about the Turkish presence since the $14^{\text {th }}$ century can be observed in these two centers and their villages. The studied monument should be evaluated as one of the representatives of the Turkish way of life in the villages of the region at the end of the $15^{\text {th }}$ and at the beginning of the $16^{\text {th }}$ centuries.

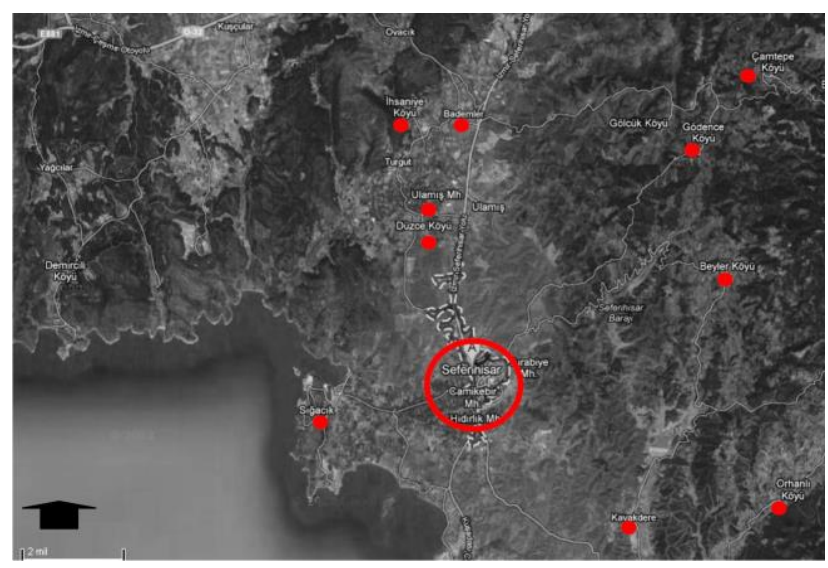

Figure 1. Seferihisar and Its villages

The village of Ulamıs is $7 \mathrm{~km}$ at the north of Seferihisar. It is on a plain at the junction point of two brooks. The bath is located 
at the northeast of the village center, nearly 150 meters in distance. It is surrounded by streets on all its four sides. While the streets on the eastern and northern sides are wide (2.5-3.5 meters), those on the western and southern sides are narrow (1.5 and 2 meters), respectively. The village houses on the opposite sides of these secondary streets are generally one storied, excluding the one with two stories at the eastern direction.

The building $(8.30 \times 10.65 \times 3.00)$ entered from a door at its north side and an irregular opening at its west side is composed of an iliklik-sicaklik (tepidarium-caldarium); two halvets (hot rooms) and a water tank at present (Figure 2).

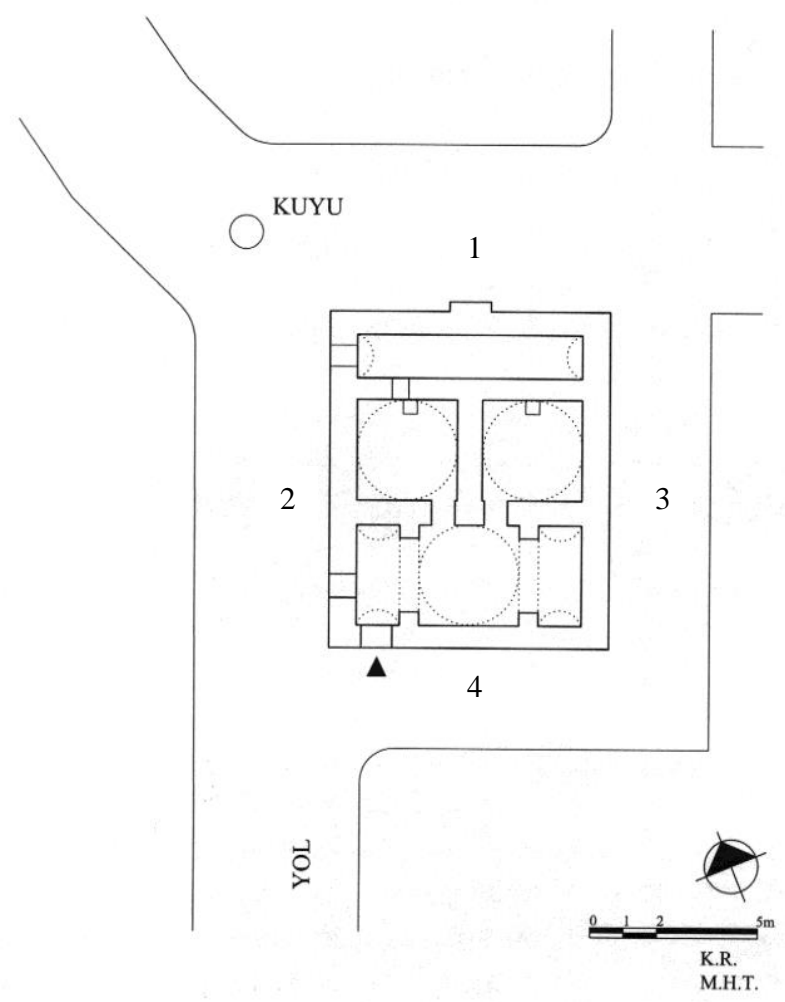

Figure 2 Plan of studied building (Hamamcioglu - Turan, Reyhan, 2005)

As revealed from the characteristic of the entrance door, the ruins of the soyunmalik (apodyterium) juxtaposing the ilikliksicaklik should be underneath the street at the 4 . The trace of the fireplace underneath the water tank and the well at the 1 of the building indicate that there might be ruins of a woodshed juxtaposing the water tank, and a courtyard at the 2 and 3 of the bath. The rectangular iliklik-sicaklik (2.50 x 5.60), running in east direction, is domed at its center and barrel vaulted on its two sides. The halvets, juxtaposing the iliklik-sicaklik at its south and north, are domed as well. This plan organization can be evaluated among one of the types in Eyice's classification of Turkish bath plans (1960) elongated rectangular sicaklik with domed central unit and two halvets. The oculi at the domes and vaults elements are the sources of illumination together with the two entrance openings mentioned in the above. In turn, the illumination level is low at the interior. Rubble stone, brick timber and mortar is used in the construction of the walls and brick and mortar is used in the construction of the domes, vaults, pendentives and the drum of the central dome at the iliklik-sicaklik. The surfaces of these elements are exposed without plastering at their exterior at present, while they are plastered at their interior. The monument is in a ruined state as a result of abandonment for years (Figure 3). Fortunately, it has been taken to the restoration program of Seferihisar Municipality, after Seferihisar has declared as a slow city in 2009. (http://www.cittaslowturkiye.org/eng/).

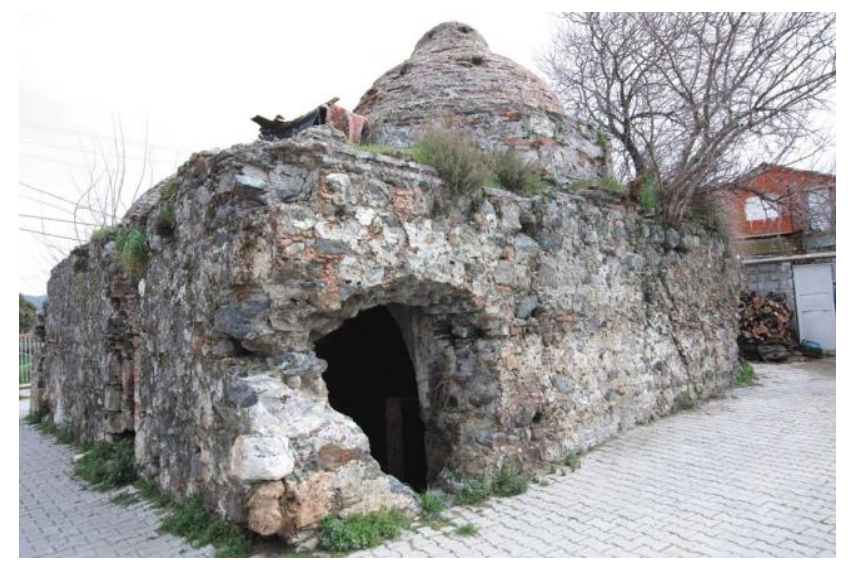

Figure 3 Studied building as viewed from the northwest

Prior to this study, a number of graduate studies were carried on Ulamıs Bath in the Department of Architectural Restoration, IYTE. A short description including a plan drawing was provided in a conservation design studio (Reyhan and Çizer, 2002; Hamamcioglu-Turan and Reyhan, 2005). Its construction technique (Reyhan, 2004), the characteristics of its lime mortars (Çizer, 2004), and the characteristics of its domes (Reyhan, 2011) were evaluated in detail in graduate thesis. A conservation project for the building was prepared within the scope of a second conservation design studio (Kanmaz, et all., 2012).

On the other hand, techniques of realistic $3 \mathrm{~d}$ modeling of historical monuments have been discussed in many studies published by CIPA (http://cipa.icomos.org/index.php?id=28) and ISPRS (http://www.isprs.org/publications/archives.aspx). In a study making an overall evaluation (Remondino and ElHakim, 2006), the historical development of research activities in image-based modeling from terrestrial images since 1980s is summarized. The unproven characteristic of the full automated methods are pointed out, and the validity of the highly manual methods are underlined.

\section{DOCUMENTATION}

The documentation process was realized in three steps: site survey; calibration and modeling.

\subsection{Site Survey}

The case study building was photographed in two phases: exterior and interior photographing phases. Each is composed of the design of partial photographs documenting building surfaces and overall photographs documenting the building / space whole from its corners. In both phases, each piece of building surface was documented with six photographs: two taken parallel to the surface with and without ladder; two taken from the right side of the parallel position with and without ladder; and two taken from the left side of the parallel position with and without ladder (Figure 4). 


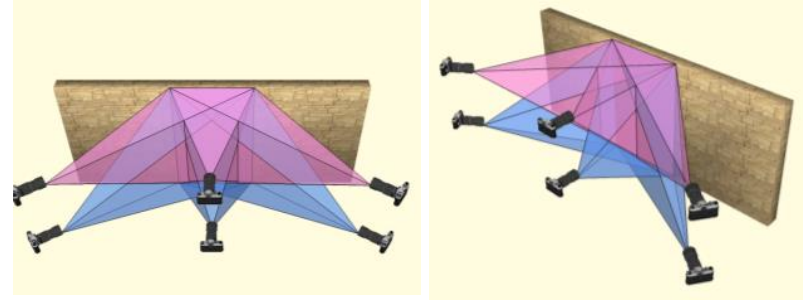

Figure 4. Schemes illustrating camera positions for partial photos

In addition to these partial photographs, overall photographs were shot across the four corners of the bath, both from street and from second story of the neighboring building (Figure 5), if possible. For the interior, photos from the corners of the spaces, with and without ladder were provided.

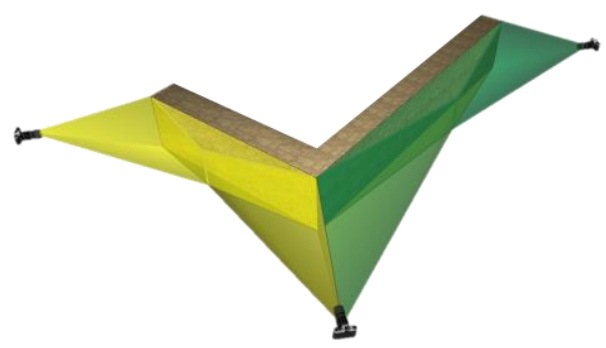

Figure 5. Scheme illustrating camera positions for overall photos

The partial photograph of the neighboring building surface piece always slightly overlapped with the previous one. The marker patterns were pasted to the facades and domes of building by using glazier's putty. In the positioning of the markers, which would act like control points in the evaluation phase; a gridal order was preferred in the facades. A homogeneous network of markers was also achieved on the domes. In each photo, eight control points were provided. For subsequent photos, minimum calibrated number of control points is three (Figure 6). But for an exact calibration; more than three control points should be viewed in a frame.
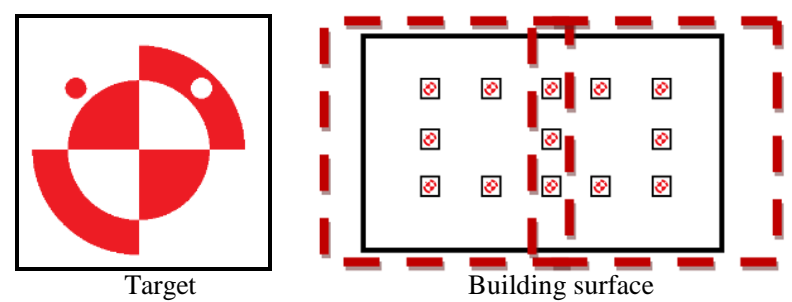

Figure 6. Paper target (a), organization of targets in succeeding partial photos

The maximum shooting distance for 1 / 50 presentations was calculated according to the below formula in relation with the constraints on each street and on the roof.

Negative scale of $1 / 50=1 / 200=$ Focal Length $/$ Distance Distance $=200 \times$ Focal Length (Swallow, et al., 2004)

Since the shooting distances for southern and western façades are limited (max. $1.5 \mathrm{~m}$ and $2 \mathrm{~m}$, respectively) because of the neighboring houses, smaller focal lengths (wide angles) were preferred and the numbers of photographs were increased. For northern and eastern façades, the focal length was relatively larger (Figure 7).

Since the shooting distance was shorter inside $(1-2 \mathrm{~m})$, it was necessary to paste more markers.

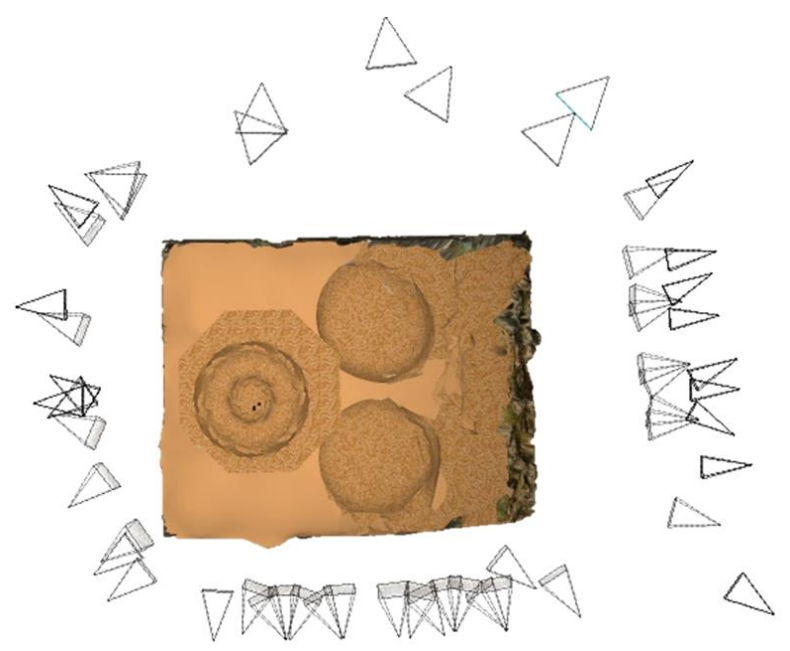

Figure 7. Placement of cameras for the exterior surfaces of the walls

\subsection{Calibration}

As the first step of the laboratory work, the shot photos were analyzed and the best two for each partial surface were selected in terms of photo quality and shooting angle variation. So, optimum numbers of photographs were selected and loaded to Tgi3d SU Photoscan version v.1.27.9 one by one starting with the photographs of the exterior wall surfaces in counterclockwise order and exterior surfaces of superstructure elements. After completing loading the partial photos of a building element such as a wall or a dome, its overall photo was added to the system. Interior photographs were evaluated in a different file.

The photographs were linked to each other with maximum 8 and minimum 3 calibration points, which were identified with paper targets. Minimization of calibration points was considered in case of short shooting distances. 2 pixels error is taken as equivalent to $2 \mathrm{~cm}$ error. Maximum 2 pixels error was accepted in the calibrations considering the fact that human eye will have difficulty in detecting errors less than half of a millimeter in the presentations $(20 \mathrm{~mm} / 50=0.4 \mathrm{~mm})$.

After the photogrammetric model composed of the $3 \mathrm{~d}$ point cloud of the calibrated points was scaled by entering a single value measured at the site, it was exported to Trimble Sketch-up version 8 together with the related photographs (Figure 8). 


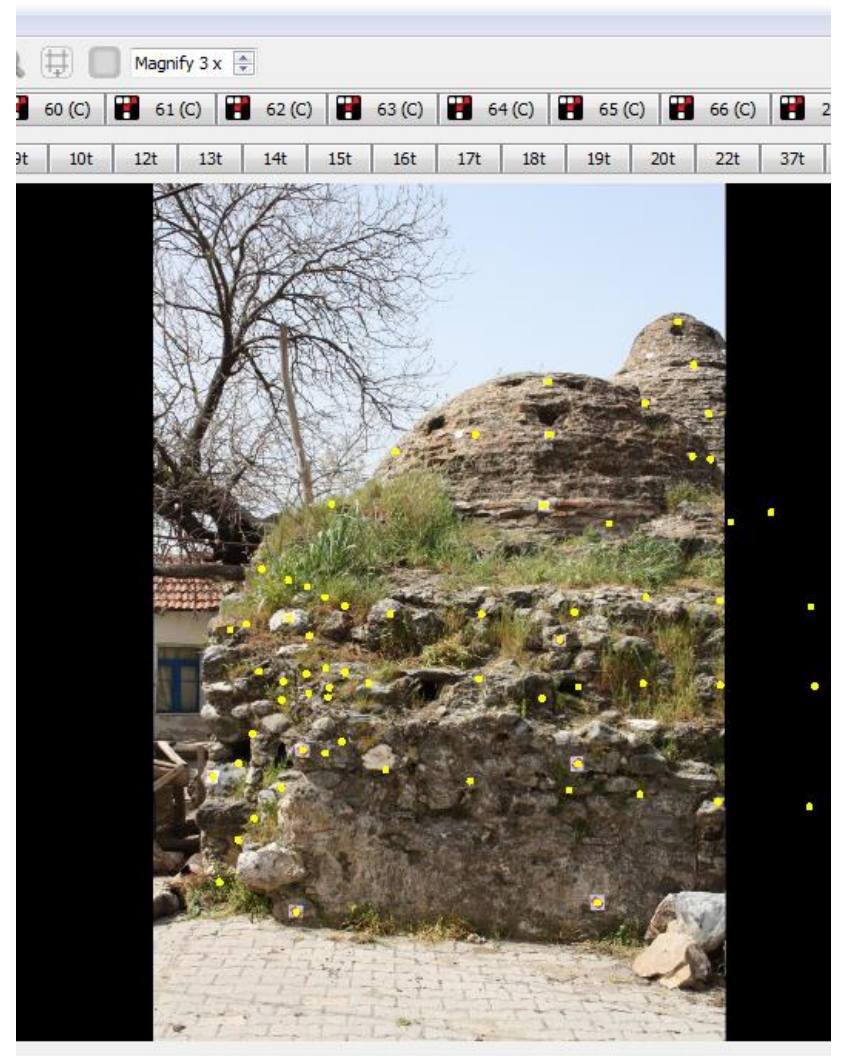

Figure 8. Point cloud indicated with yellow dots

\subsection{Modeling}

Building surfaces visible on each photo were modeled one by one in counter clockwise order. The photo with highest number of successful meshes for the same building surface was selected among the views taken from different positions. If none of the views provides successful meshing (Figure 9), then calibration was repeated. As a result, a mesh system for the bath whole was constituted. The photos shot parallel to the related building surfaces were projected onto the meshes in order to provide texture.

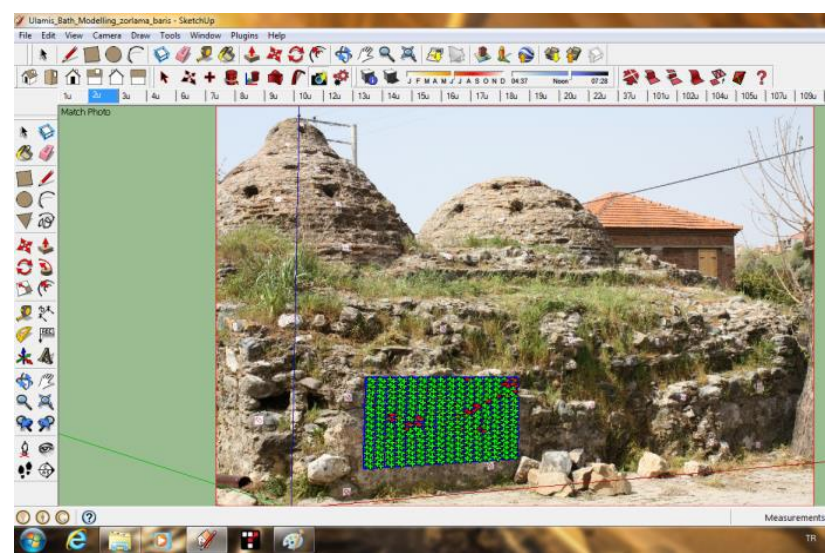

Figure 9. Up sampling of a mesh group

\section{DISCUSSION AND CONCLUSION}

In this study, the potential of new manual photogrammetric evaluation software Tgi3D Photoscan SU 1.27 was tested for a historical building. The end result model based on experiments with targets presents photorealistic details of the studied Ottoman bath. The accuracy is measurable with the error data provided by the software. The exterior surfaces including those of the walls and the vaults of the iliklik-sicaklik, the drum of the major dome, and bottom zones of all domes were modeled successfully (Figure 10). These positive results were achieved in the presence of the conditions mentioned in the below:

- Providing targets on the building surfaces prior to shooting

- Coordinating scale - lens - distance relations

- Designing shooting angles

- Providing sufficient illumination during shooting

- Providing a parallel shot to each piece of building surface

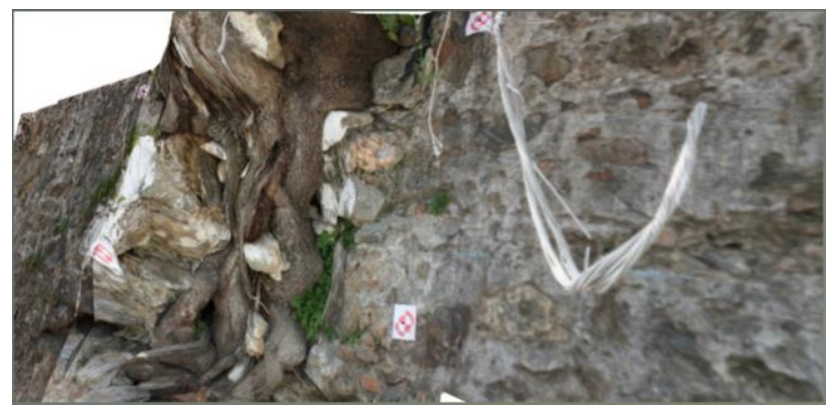

Figure 10. Presentation of photorealistic details of historical morphologies.

Despite these positive results, there were some problems observed in the model gained with the targets. These may be listed as distortion, blurring and incompleteness. Distortion could be seen in the edges of building elements stemming from unrealistic mesh formation and photo projection. E.g. the edge between the vault of the water tank and the wall of the halvets, the edges of the domes that is in relation with the sky. Distortion parts were erased by tool and unrealistic shapes were cleaned (Figure 11).

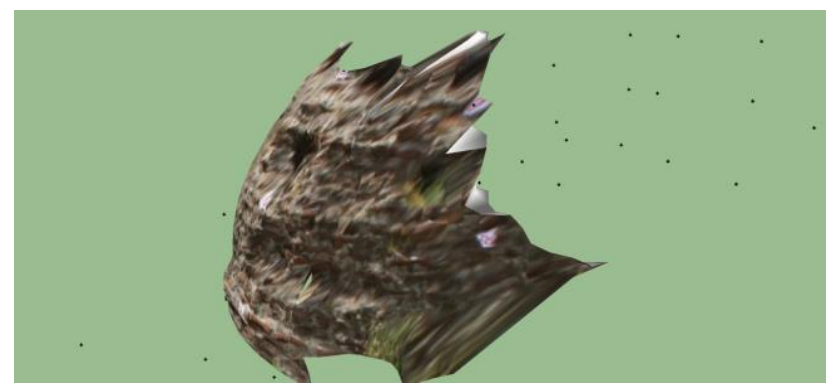

Figure 11. Distortion of surface material

In case of presence of dense grass on the surface, e.g. the exterior surface of the vault of the water tank, blurring occurs in the related model. This stems from continuous change of position of grass due to breeze during shooting. Cutting grass on the surfaces prior to shooting is recommended. 
Systematic shooting of dome surfaces could not be made especially at their top zones because it was impossible to stand up in an appropriate position. In turn, the geometry and/or the surface texture were documented partially. The model was completed with comparative study within the building. That is to say, the documented piece was copied to the undocumented parts of the dome (Figure 12). These areas were indicated with beige color and dots on the presentation model. The areas with correct geometry, but insufficient texture quality were differentiated with beige render without dots. Utilization of an unmanned aerial vehicle for shooting in these zones may be helpful.

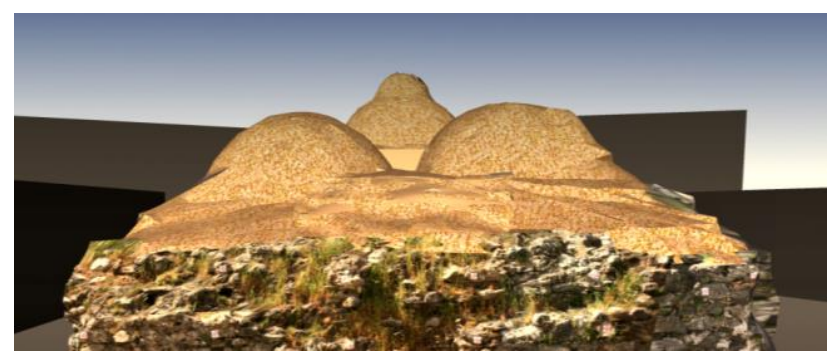

Figure 12. Eastern elevation

In case of limited illumination, as in the interior of the bath, the model could not be completed (Figure 13). So, the photographs should be repeated after provision of an artificial illumination system.

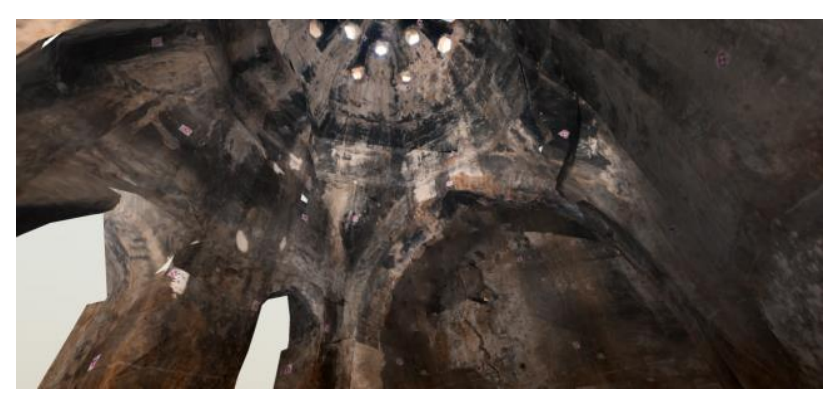

Figure 13. Iliklik/sicaklik, perspective view from the model.

In case of lack of targets, the exterior surfaces of majority of the walls could be modeled, but the wall on the narrow street at the south and the superstructure could not be modeled (Figure 14).

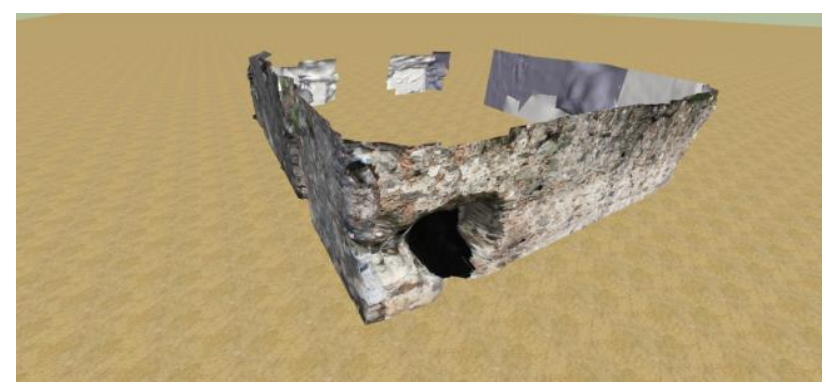

Figure 14. Modeling without targets

From the view point of time consumption, site work of the documentation was completed in a short time, but the laboratory work requires long working hours (Table 1). As the duration of each experiment reveals, evaluation time decreases as the operator gets experienced.

\begin{tabular}{|c|c|c|c|c|c|c|}
\hline \multicolumn{7}{|c|}{ Duration of documentation phases } \\
\hline & $\begin{array}{l}\text { Photogra } \\
\text { phic } \\
\text { document } \\
\text { ation of } \\
\text { exterior } \\
\text { surfaces }\end{array}$ & $\begin{array}{c}\text { Calibrati } \\
\text { on of } \\
\text { exterior } \\
\text { photogra } \\
\text { phs }\end{array}$ & $\begin{array}{c}\text { Modeling } \\
\text { of } \\
\text { exterior } \\
\text { photogra } \\
\text { phs }\end{array}$ & $\begin{array}{l}\text { Photogra } \\
\text { phic } \\
\text { document } \\
\text { ation of } \\
\text { interior } \\
\text { surfaces }\end{array}$ & $\begin{array}{c}\text { Calibrati } \\
\text { on of } \\
\text { interior } \\
\text { photogra } \\
\text { phs }\end{array}$ & $\begin{array}{c}\text { Modeling } \\
\text { of } \\
\text { interior } \\
\text { photogra } \\
\text { phs }\end{array}$ \\
\hline 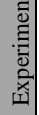 & $\begin{array}{c}\sim 1 \\
\text { workday }\end{array}$ & $\begin{array}{c}\sim 20 \\
\text { workdays }\end{array}$ & $\begin{array}{c}\sim 25 \\
\text { workdays }\end{array}$ & $\begin{array}{c}\sim 1.5 \\
\text { workdays }\end{array}$ & $\begin{array}{c}\sim 21 \\
\text { workdays }\end{array}$ & $\begin{array}{c}\sim 42 \\
\text { workdays }\end{array}$ \\
\hline \multirow[t]{2}{*}{1} & $\begin{array}{c}\sim 0.5 \\
\text { workday }\end{array}$ & $\begin{array}{c}\sim 3 \\
\text { workdays }\end{array}$ & $\begin{array}{c}\sim 21 \\
\text { workdays }\end{array}$ & $\begin{array}{c}\sim 1 \\
\text { workday }\end{array}$ & $\begin{array}{c}\sim 21 \\
\text { workdays }\end{array}$ & $\begin{array}{c}\sim 30 \\
\text { workdays }\end{array}$ \\
\hline & - & $\begin{array}{c}\sim 10 \\
\text { workdays }\end{array}$ & $\begin{array}{c}\sim 61 \\
\text { workdays }\end{array}$ & - & - & - \\
\hline 2 & $\begin{array}{c}1 \\
\text { workday }\end{array}$ & $\begin{array}{c}\sim 10 \\
\text { workdays }\end{array}$ & $\begin{array}{c}\sim 14 \\
\text { workdays }\end{array}$ & - & $\begin{array}{c}\sim 10 \\
\text { workdays }\end{array}$ & $\begin{array}{c}\sim 20 \\
\text { workdays }\end{array}$ \\
\hline 3 & $\begin{array}{c}\sim 0,5 \\
\text { workday }\end{array}$ & $\begin{array}{c}\text { 3 } \\
\text { workdays }\end{array}$ & $\begin{array}{c}\sim 7 \\
\text { workdays }\end{array}$ & - & - & - \\
\hline
\end{tabular}

Table 1. Work duration

Study the structure of the bath, which is necessary for modeling site in detail in a comprehensive manner all the photos were taken. The captured images sequentially one at a time and then mapping the digital environment carried out the calibration process. 3D pictures 3D environment Tgi transferred calibrated with the help of plug-in Sketch Up program exteriors and interiors combined with modeled separately. Study the structure of the baths Ulamış Tgi sketch Up calibration and 3D modeling program with the principles of SU Photoscan determined as follows:

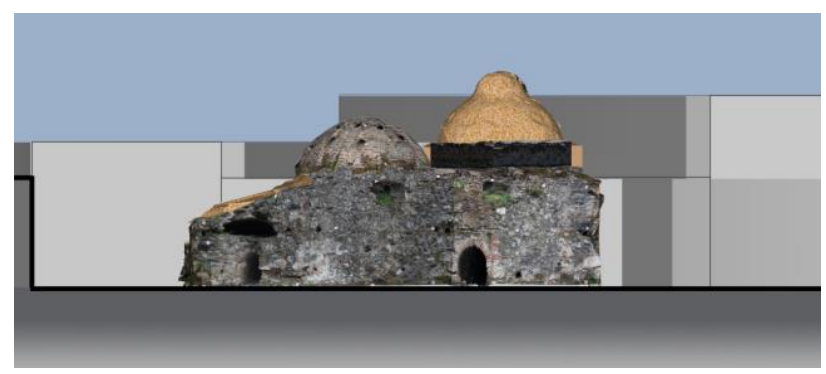

Figure 15. Northern elevation

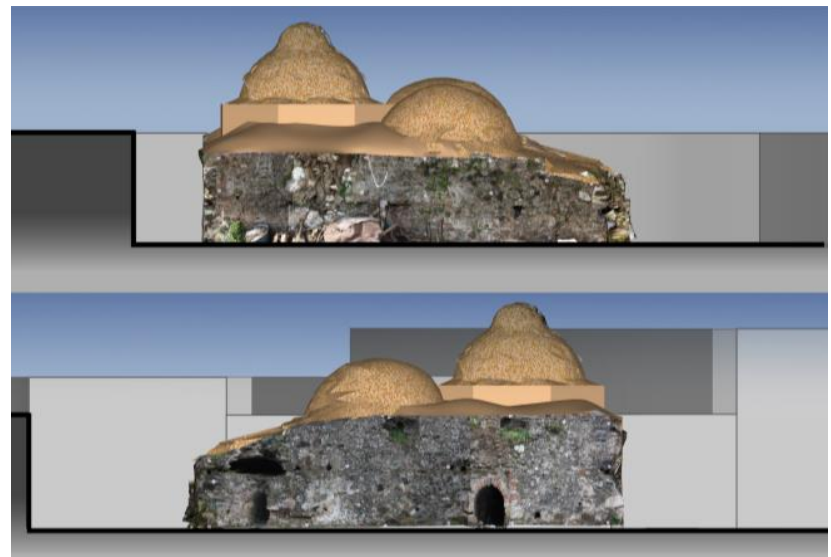

Figure 16. Above: Southern Elevation; Below: Northern elevation 


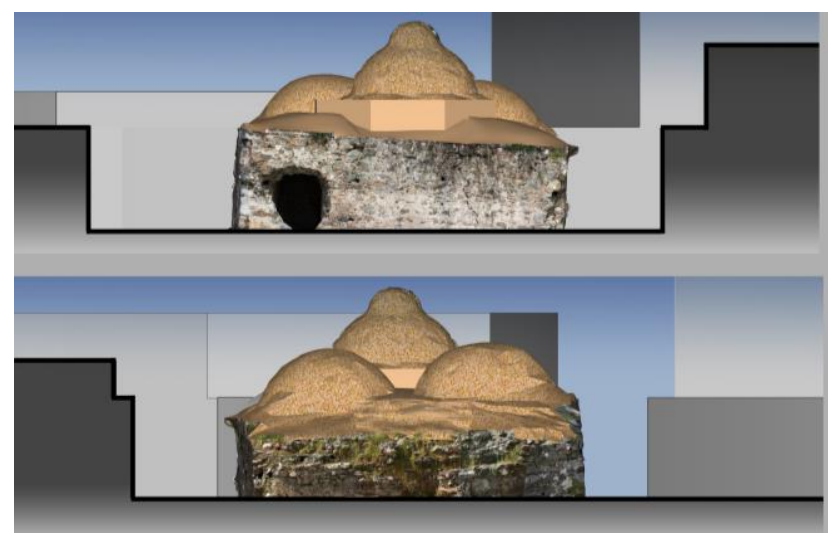

Figure 17. Above: Western Elevation; Below: Eastern elevation

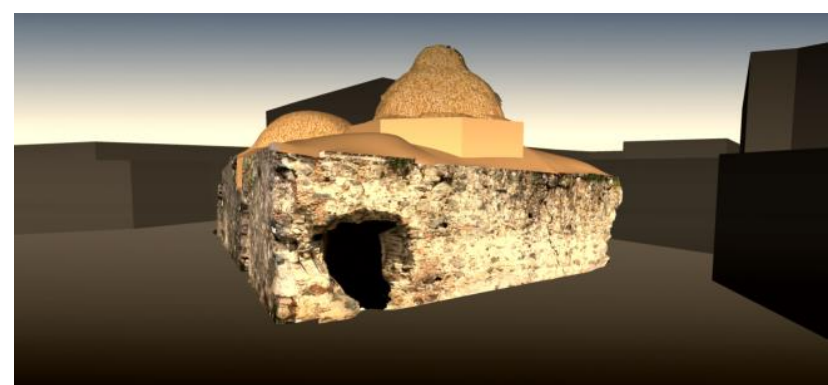

Figure 18. North west perspective view

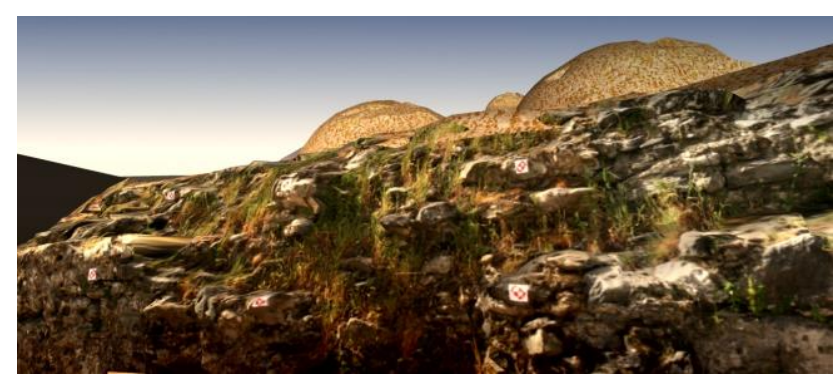

Figure 19. Detailed perspective view

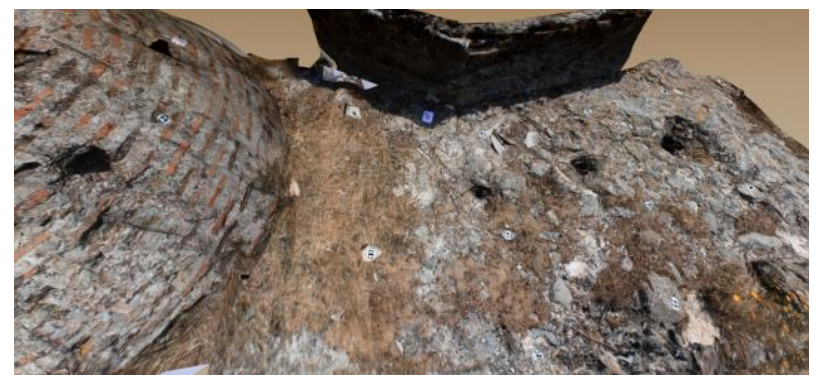

Figure 20. Detailed part of North West in superstructure

\section{REFERENCES}

Reyhan, K., Çizer, Ö. 2002. "Restoration Project of Büyük Hamam in Seferihisar, İzmir", Studio Course: RES 502 Design in Architectural Restoration II, Supervisor: Assist. Prof. Dr. Mine Hamamcioğlu-Turan, the Graduate Program of Architectural Restoration, İzmir Institute of Technology, İzmir, Turkey.
Hamamcioğlu-Turan, M., Reyhan, K., 2005. Urla-Seferihisar Bölgesindeki Türk Dönemi Hamamları (Turkish Period Baths in Urla-Seferihisar Region), Arkitekt, No: Ağustos-Eylül 2005/ $501,10-24$.

Kanmaz, M.B., Çağlıyurt, A., Karayılmaz, H., Ağaç, G., Kıncı, D., 2012. "Restoration Project of Ulamış Hamam in Seferihisar, İzmir", Studio Course: RES 502 Design in Architectural Restoration II, Supervisor: Assoc. Prof. Dr. Selim Sarp Tunçoku and Res. Assist. Dr. F. Nurşen Kul, the Graduate Program of Architectural Restoration, İzmir Institute of Technology, İzmir, Turkey.

\section{Digital Camera \\ CANON EOS 450D Digital SLR}

Computer

Intel i5, 1,8 GHz, 4 GB DDR3 RAM, 1GB AMD Radeon HD 6470M Graphic Card 